\title{
NILAI KECERNAAN BK DAN BO TEPUNG GAPLEK DARI BERBAGAI JENIS TANAMAN SINGKONG (Manihot utilissima) SECARA IN VITRO
}

\author{
In Vitro Digestibility of Cassava Meal from Various Types of Cassava \\ Plants (Manihot utilissima)
}

\author{
Gali Dwi Prasetyo ${ }^{1)}$, Aprilia Dwi Kartika ${ }^{1)}$ dan Mashudi ${ }^{2)}$ \\ 1) Mahasiswa Minat Nutrisi dan Makanan Ternak, Fakultas Peternakan, Universitas Brawijaya Jalan Veteran, \\ Ketawanggede, Kec. Lowokwaru, Kota Malang, Jawa Timur 65145 \\ 2) Dosen Minat Nutrisi dan Makanan Ternak, Fakultas Peternakan, Universitas Brawijaya Jalan Veteran, \\ Ketawanggede, Kec. Lowokwaru, Kota Malang, Jawa Timur 65145 \\ Email: galidwiprastyo05@gmail.com
}

\begin{abstract}
ABSTRAK
Penelitian ini bertujuan untuk mengevaluasi nilai kecernaan BK dan BO tepung gaplek dari berbagai jenis tanaman singkong (Manihot utilissima) serta mendapatkan informasi tentang tepung gaplek dari jenis tanaman singkong apa yang paling baik untuk diberikan pada ternak ruminansia. Materi yang digunakan dalam penelitian ini adalah tepung gaplek dari berbagai jenis tanaman singkong, cairan rumen dari sapi Peranakan Friesian Holstein (PFH) betina berfistula, serta alat dan bahan kimia untuk mengukur nilai dari kecernaan $B K$ dan BO secara in vitro. Metode dalam penelitian ini menggunakan Rancangan Acak Kelompok (RAK) dengan 5 perlakuan dan 3 kelompok berdasarkan perbedaan waktu pengambilan cairan rumen. Perlakuan terdiri dari P1: Tepung Gaplek 100\% jenis singkong Gatot Kaca, P2: Tepung Gaplek 100\% jenis ketela kuning, P3: Tepung Gaplek 100\% jenis singkong Manalagi, P4: Tepung Gaplek 100\% jenis singkong Srintil, P5: tepung Gaplek 100 $\%$ jenis singkong Ketan. Hasil penelitian tersebut dianalisis menggunakan analisis ragam, apabila hasil uji menunjukkan adanya perbedaan maka dilakukan uji lanjutan menggunakan Uji Jarak Berganda Duncan (DMRT). Hasil analisis menunjukkan bahwa setiap jenis singkong mempunyai kandungan nutrien yang tidak berbeda jauh, sehingga menyebabkan perlakuan tidak memberikan perbedaan yang nyata $(P>0,05)$ terhadap nilai dari kecernaan bahan organik $(K c B O)$ dan kecernaan bahan kering $(K c B K)$ secara in vitro. Perlakuan terbaik terdapat pada P2 yaitu jenis singkong Kuning dengan hasil yang menunjukkan nilai tertinggi pada kecernaan bahan kering (KcBK) yaitu 93,78\% dan kecernaan bahan organik (KcBO) yaitu 95,83\%.
\end{abstract}

Kata kunci: Tepung gaplek, kecernaan bahan kering, kecernaan bahan organik, in vitro.

How to Cite:

Prasetyo, G.P., Kartika, A.D., \& Mashudi. (2019). Nilai Kecernaan Bk dan Bo Tepung Gaplek dari Berbagai Jenis Tanaman Singkong (Manihot utilissima) Secara in Vitro. Jurnal Nutrisi Ternak Tropis 2 (2) 33-37
*Corresponding author:

Gali Dwi Prasetyo

Email: galidwiprastyo05@gmail.com

Fakultas Peternakan, Universitas Brawijaya Jalan

Veteran, Ketawanggede, Kec. Lowokwaru, Kota Malang, Jawa Timur 65145 


\section{ABSTRACT}

The aim of this study was to evaluate the nutritional value of cassava flour from various types of cassava plants (Manihot utilissima). Research was arranged in randomized block design, 5 treatments with 3 replications as a group. The treatments were: T1: Cassava flour 100\% Gatot Kaca cassava type, T2: cassava meal 100\% Kuning type, T3: cassava meal 100\% Manalagi type, T4: cassava meal 100\% Srintil type, T5: cassava meal 100\% Ketan type. The group in this experiment was the classified based on rumen fluid. Data were analyzed using Analysis of variance (ANOVA) and Duncan's Multiple Range Test (DMRT). There was not significant effect $(P>0.05)$ on dry matter digestibility $(D M D)$ and digestibility of organic matter (OMD) in vitro). The best treatment was T2 (Kuning cassava type) which showed DMD 93.78\% and OMD 95.83\%.

Keywords: Cassava meal, manihot utilissima, in vitro, nutrient content, gas production, digestibility

\section{PENDAHULUAN}

Hijauan merupakan salah satu pakan sumber serat tinggi bagi ternak ruminansia. Ternak ruminansia memiliki kemampuan yang luar biasa dalam mengkonversikan bahan pakan yang berkualitas rendah menjadi produk hasil ternak yang berkualitas tinggi. Ternak ruminansia berperan dalam penyediaan protein hewani yang memiliki nilai gizi tinggi. Populasi ternak ruminansia semakin meningkat dari tahun ke tahun di Indonesia.

Peningkatan populasi ternak ini mengakibatkan kebutuhan pakan ternak meningkat, karena pakan mempunyai peran penting bagi produktivitas ternak sehingga ketersediaan pakan secara kontinyu merupakan persyaratan mutlak bagi usaha peternakan. Permasalahan yang kemudian muncul adalah ketersediaan pakan secara kualitas dan kuantitas untuk memenuhi kebutuhan nutrisi dari ternak, sehingga produktivitas ternak rendah. Hal ini disebabkan karena mutu pakan terutama hijauan yang bervariasi dan tergantung pada musim. Sebagian besar wilayah Indonesia, pada saat musim hujan pakan hijauan mudah diperoleh sedangkan saat kemarau sangat sulit.

Hijauan merupakan bahan pakan yang mempunyai kandungan serat tinggi yang dibutuhkan ternak terutama ternak ruminansia. Pemberian pakan juga tidak bisa hanya diberikan berupa hijauan saja karena perlunya sumber nutrisi lainnya, sehingga perlu ditambahkan jenis pakan lain berupa konsentrat. Perbandingan pemberian pakan hijauan dan konsentrat didasarkan pada kebutuhan sapi dan ketersediaan bahan pakan tersebut (Gustiar dkk., 2014). Salah satu bahan pakan yang dapat digunakan sebagai penyusun konsentrat adalah tepung gaplek.

Tepung gaplek adalah bahan pakan yang mempunyai kandungan nutrisi antara lain energi $3000 \mathrm{kcal}$ per $\mathrm{kg}$, protein kasar $3,3 \%$, lemak kasar 5,3\%, phospor $0,17 \%$, dan kalsium 0,57\% (Tillman et al., 1991). Tingginya kandungan karbohidrat dalam gaplek mengakibatkan tingkat degradasi di dalam rumen juga tinggi dan berlangsung cepat apabila diimbangi dengan pemberian pakan kaya sumber N. Di Indonesia terdapat beberapa varietas tanaman singkong untuk diolah menjadi tepung gaplek. Salah satu metode sederhana untuk mengevaluasi kualitas tepung gaplek dari berbagai varietas tanaman singkong dapat menggunakan metode in vitro. Metode in vitro adalah metode pengukuran kecernaan pakan yang dilakukan secara kimiawi dengan mengggunakan tabung fermentasi di Laboratorium dengan menirukan proses pencernaan alami yang terjadi pada tubuh ternak ruminansia (Hartutik, 2012). 


\section{MATERI DAN METODE}

Materi yang digunakan dalam penelitian ini adalah tepung gaplek dari berbagai varietas tanaman singkong yang diperoleh dari petani singkong di daerah Karangploso, Malang.

Penelitian ini menggunakan metode percobaan dengan Rancangan Acak Kelompok (RAK) yang terdiri dari 5 perlakuan (jenis singkong) dan 3 kali ulangan sebagaikelompok. Kelompok pada penelitian ini adalah perbedaan waktu pengambilan cairan rumen. Berikut perlakuan dalam penelitian:

P1: Tepung Gaplek 100\% jenis singkong Gatot Kaca

P2: Tepung Gaplek 100\% jenis singkong Kuning
P3: Tepung Gaplek 100\% jenis singkong Manalagi

P4: Tepung Gaplek 100\% jenis singkong Serintil

P5: Tepung Gaplek 100\% jenis singkong Ketan

Parameter yang diamati meliputi kualitas kandungan nutrisi, produksi gas, kecernaan bahan kering (KcBK) dan kecernaan bahan organik $(\mathrm{KcBO})$ secara $I n$ Vitro.

\section{HASIL DAN PEMBAHASAN}

\section{Kandungan Nutrisi Pakan}

Hasil analisis kandungan nutrisi tepung gaplek dari berbagai varietas singkong dapat dilihat pada Tabel 1 .

Tabel 1. Kandungan nutrisi tepung gaplek dari berbagai jenis tanaman singkong yang digunakan pada penelitian.

\begin{tabular}{lccccc}
\hline \multicolumn{1}{c}{ Sampel } & BK\% & BO\% & PK\% & LK\% & SK\% \\
\hline P1 (Singkong Gatot kaca) & 91,77 & 97,58 & 2,77 & 1,01 & 3,41 \\
P2 (Singkong Kuning) & 92,76 & 97,72 & 3,84 & 0,35 & 3,91 \\
P3 (Singkong Manalagi) & 92,11 & 96,56 & 1,86 & 0,40 & 2,99 \\
P4 (Singkong Srintil) & 92,37 & 98,02 & 2,59 & 0,92 & 3,22 \\
P5 (Singkong Ketan) & 92,25 & 97,36 & 2,30 & 0,72 & 2,93 \\
\hline
\end{tabular}

Keterangan:*) Hasil analisis di Laboratorium Nutrisi dan Makanan Ternak Fakultas Peternakan Universitas Brawijaya (Berdasarkan 100\% bahan kering) (2018).

Hasil penelitian menunjukkan bahwa kandungan BK tepung gaplek dari berbagai jenis tanaman singkong berkisar antara $91,77-92,76 \%$, hal ini menunjukkan bahwa sampel yang digunakan pada penelitian dalam bentuk kering sehingga memiliki kandungan air yang rendah yaitu sekitar 10\%. Kandungan BK yang digunakan pada penelitian lebih tinggi dibandingkan dengan tepung gaplek yang digunakan di Lolit Sapi Potong, Grati, Pasuruan (2004) yaitu sebesar 87,02\% .

Kandungan PK tepung gaplek dari berbagai jenis tanaman singkong berkisar antara $1,86-3,84 \%$, dibandingkan dengan tepung gaplek yang digunakan di Lolit Sapi
Potong Grati, Pasuruan (2004) yaitu 2,41\%. Menurut Soebianto (1993) bahwa tepung gaplek memiliki kandungan PK sebesar 3,31\%. Kandungan PK tepung gaplek tersebut hampir sama dengan tepung gaplek yang digunakan dalam penelitian, hal ini menunjukkan bahwa tepung gaplek memiliki kualitas setara ditinjau dari kandungan. Protein dalam pakan sangat penting dalam penyediaan sumber nitrogen untuk menunjang pertumbuhan mikroba di dalam rumen.

Ternak ruminansia, pakan dengan kadar protein yang tinggi dapat dimanfaatkan sebagai sumber nitrogen untuk pertumbuhan mikroba dalam rumen. 
Pertumbuhan mikroba rumen yang cepat dapat meningkatkan degradasi pakan yang berserat tinggi sehingga akan meningkatkan efesiensi pemanfaatan pakan non konvensional yang berpotensi tinggi (serat kasar dan protein yang tinggi). Kebutuhan energi ternak ruminansia berasal dari serat, dimana SK tepung gaplek yang digunakan dalam penelitian berkisar 2,934\%-3,914\% . Berdasarkan hasil analisis pada Tabel 1. kandungan SK lebih rendah dibandingkan tepung gaplek yang digunakan di Lolit Sapi Potong Grati, Pasuruan yaitu 8,93\%. Tepung gapek yang digunakan dalam penelitian diolah dari singkong tanpa menyertakan kulitnya, sedangkan tepung gaplek yang digunakan di Lolit Sapi Potong Grati, Pasuruan diduga dalam proses pembuatan tepung gaplek kulit singkong di sertakan. Suprapto dkk (2013) yang menyebutkan bahwa serat kasar merupakan sumber energi utama bagi ternak ruminasia. Kandungan SK tertinggi ditunjukkan oleh jenis singkong Kuning yaitu 3,914\%, sedangkan SK terkecil pada jenis singkong Ketan yaitu 2,934\%. Menurut Anggorodi (1994), semakin tinggi serat kasar pada bahan pakan menyebabkan semakin rendah daya cerna bahan pakan tersebut. Sebaliknya bahan pakan dengan serat kasar yang rendah pada akan lebih mudah dicerna oleh ternak, karena hal itu berhubungan dengan ketebalan dinding sel dari bahan pakan tersebut sehingga mudah ditembus oleh getah pencernaan. Tillman et al., (1998) menambahkan bahwa daya cerna mempunyai hubungan yang erat dengan komposisi kimiawinya, terutama kandungan serat kasarnya.

\section{Kecernaan Bahan Kering (KcBK) dan Kecernan Bahan Organik (KcBO) Secara In Vitro}

Nilai rataan kecernaan bahan kering $(\mathrm{KcBK})$ dan nilai kecernaan bahan organik (KcBO) tepung gaplek dari berbagai varietas singkong secara in vitro dapat dilihat pada Tabel 2 .

Tabel 2. Nilai Rataan Uji Kecernaan Bahan Kering (KcBK) dan Kecernaan Bahan

Organik (KcBO) tepung gaplek dari berbagai jenis singkong inkubasi 72 jam.

\begin{tabular}{lcc}
\hline \multicolumn{1}{c}{ Sampel } & KcBK \% & KcBO \% \\
\hline P1 (Singkong Gatot Kaca) & $92,40 \pm 2,96$ & $94,04 \pm 3,48$ \\
P2 (Singkong Kuning) & $93,78 \pm 2,59$ & $95.83 \pm 3,06$ \\
P3 (Singkong Manalagi) & $90,90 \pm 3,03$ & $91,90 \pm 6,54$ \\
P4 (Singkong Srintil) & $92,24 \pm 2,80$ & $92,79 \pm 8,26$ \\
P5 (Singkong Ketan) & $91,98 \pm 2,27$ & $93,50 \pm 5,60$
\end{tabular}

Keterangan: Perlakuan memberikan pengaruh yang tidak nyata terhadap kecernaan bahan kering $(\mathrm{KcBK})$ dan kecernaan bahan organik $(\mathrm{KcBO})(\mathrm{P}>0,05)$.

Hasil uji statistik menujukkan bahwa perlakuan yang diberikan tidak berpengaruh nyata $(\mathrm{P}>0,05)$ terhadap kecernaan bahan kering $(\mathrm{KcBK})$ dan kecernaan bahan organik (KcBO). Semakin meningkatnya KcBK, maka itu artinya semakin meningkat $\mathrm{KcBO}$ dan semakin tinggi peluang nutrisi yang dapat dimanfaatkan ternak untuk produksi dan begitu juga sebaliknya. Bahan kering terdiri dari abu dan bahan organik yang ada didalamnya sehingga tinggi rendahnya KcBK akan berpengaruh juga terhadap tinggi rendahnya $\mathrm{KcBO}$ dalam suatu pakan (Setiyaningsih, dkk, 2012).

Nilai KcBK dan KcBO tertinggi rerdapat pada $\mathrm{P} 2$ yaitu jenis singkong Kuning dan yang paling rendah pada P3 jenis singkong Manalagi. Hal ini dikarenakan singkong Kuning memiliki kandungan protein yang tinggi dibanding dengan jenis lainnya yaitu 3,836\% (Tabel 1). Menurut Jayanegara, Sofyan, Makkar, Becker (2009), bahwa nilai kecernaan dipengaruhi secara positif oleh kandungan 
protein, hal ini dikarenakan protein merupakan komponen yang sangat mudah didegradasi oleh mikroba rumen, kecuali protein yang diproteksi menggunakan senyawa tertentu. Tinggi maupun rendahnya kecernaan pada penelitian ini erat kaitannya dengan besar atau kecilnya jumlah protein yang terdegradasi oleh rumen menjadi ammonia.

Berdasarkan pada Tabel 2. dapat diartikan bahwa singkong Kuning memiliki kualitas tepung gaplek yang tinggi. Hal ini sebanding dengan pernyataan McDonald et $a l$.. (2002), bahwa komposisi kimia pakan mempengaruhi kecernaan dari pakan terutama protein dan pakan serat tinggi. Pakan dengan kualitas baik diprediksi juga memiliki nutrisi yang baik pula dengan syarat pakan tersebut palatable. Salah satu faktor penentu kualitas pakan adalah kecernaan pakan tersebut. Semakin baik kualitas pakan yang digunakan, maka absorbsi zat nutrisi pakan juga cepat sehingga mampu meningkatkan produksi ternak.

\section{KESIMPULAN DAN SARAN}

Berdasarkan hasil penelitian yang telah dilakukan diperoleh kesimpulan bahwa, evaluasi tepung gaplek dari berbagai jenis tanaman singkong mempunyai kandungan nutrisi yang hampir sama dengan hasil terbaik yaitu pada perlakuan P2 jenis Singkong Kuning ditinjau dari KcBK dan KcBO. Saran dari penelitian ini adalah dilakukannya penelitian lanjutan secara in vivo untuk mengetahui respon ternak secara langsung dan tingkat palatabilitas.

\section{DAFTAR PUSTAKA}

Anggorodi, R. (1994). Ilmu Makanan Ternak Umum (5th ed.). Jakarta: PT. Gramedia Pustaka Utama.

Gustiar, F., Suwignyo, R. A., Suheryanto, \& Munandar. (2014). Reduksi gas metan (CH4) dengan meningkatan komposisi konsentrat dalam pakan ternak sapi. Jurnal Peternakan Sriwijaya, 3(1). https://doi.org/10.33230/JPS.3.1.2014.1728

Hartutik. (2012). Metode Analisis Mutu Pakan. Malang: UB Press.

Jayanegara, A., Sofyan, A., Makkar, H. P., \& Becker, K. (2009). Kinetika produksi gas, kecernaan bahan organik dan produksi gas metana in vitro pada hay dan jerami yang disuplementasi hijauan mengandung tanin. Media Peternakan, 32(2), 120-129.

Lolit. (2004). Pengembangan Usaha Sapi Potong. Lokakarya Nasional Sapi Potong.

McDonald, P., Edward, R., \& Greenhalgh, J. F. (1988). Animal Nutrition. (L. J. Willey \& Son, Eds.). New York.

Setiyaningsih, K. D., Christiyanto, M., \& Sutarno, S. (2012). Kecernaan bahan kering dan bahan organik secara in vitro hijauan desmodium cinereum pada berbagai dosis pupuk organik cair dan jarak tanam. Animal Agriculture Journal, 1(2), 51-63.

Soebiyanto, \& Kusoemo, T. A. (1993). HFS dan Industri Ubi Kayu Lainny. Jakarta: PT Gramedia Pustaka Utama.

Suprapto, H., Suhartati, F., \& Widiyastuti, T. (2014). Kecernaan serat kasar dan lemak kasar complete feed limbah rami dengan sumber protein berbeda pada kambing pernakan etawa lepas sapih. Jurnal Ilmiah Peternakan , 1(3), 938946.

Tillman, A., Hartadi, H., Reksohadiprodjo, S., Prawirokusumo, S., \& Lebdosoekjo, S. (1998). Ilmu Makanan Ternak Dasar. Yogyakarta: Gadjah Mada University Press. 